\title{
Reciprocity between financials and Social Performance in Microfinance Institutions: Transparency and Ownership Structure used as Moderating Variables
}

\author{
Ghulam Abbas \\ PhD Scholar \\ Facultyof Business Administration \\ IBA Sindh University Jamshoro \\ abbasaliphd@gmail.com \\ Saifullah Shakir \\ PhD Scholar \\ Facultyof Management Science \\ Hamdard University HIMS Karachi \\ Saifullahshakir@gmail.com

\section{Rashid Hayat} \\ PhD Scholar \\ Institute of Business Managementand Administrative Sciences (IBMAS) \\ The Islamia University Bahawalpur, Pakistan \\ rhqazi@yahoo.com \\ Mohsin Ali \\ PhDScholar \\ SchoolEconomics Finance and Banking (SEFB) \\ Universitiof Utara Malaysia (UUM) \\ mohsinpak@yahoo.com \\ Muhammad Kamran \\ PhDScholar \\ Institute of Business Managementand Administrative Sciences (IBMAS) \\ The Islamia University Bahawalpur, Pakistan \\ kamibhutta@live.com
}

\begin{abstract}
The objective is to check performance of microfinance loan in context of social performance and its various dimensions i.e health, education, clean water and women empowerment. Likewise study also test moderating effect of loan transparency and ownership structure between micro-finance loan and social performance. The survey-based approach was used with a sample size of 350. Data was collected through self-administered questionnaires from the
\end{abstract}


client of a microfinance institution in a different region of Sindh. In response 273 completed questionnaires were received from respondent and response rate was 78\%. Among those 273 questionnaires, 19 were unengaged responses so were considered unsuitable for analysis and reaming 254 questionnaire were used for data analysis. The Smart PLS Technique was used for data estimation in this study. Findings of the existing study portrays significant impact of microfinance loan on social performance as well as on its various dimensions i.e Health, Education, Clean Water and women empowerment. The moderating impact of transparency is positively significant in social performance, and the moderating impact of ownership structure in social performance is showing negative significant impact. The result of this study can lead to significant contributions and provide a better understanding and influence of transparency and ownership structure on the social performance of microfinance loans as well as dimensions of social performance. Financial sources of micro finance loan would be beneficial for poor people, micro enterprise and epically for empowerment of women in emerging economy. Micro finance institutions should control in interest rate and create an awareness regarding utilization of loan and timely repayment among their customers.

Keywords: Micro finance Loan, Social performance, Ownership structure, Transparency

\section{Introduction}

The microfinance sector has developed as an innovative tool to overcome poverty. It has been implemented through a structure called microfinance institutions (MFIs), which provides loan and financial services to low-income household, small business, and entrepreneurs, particularly that business run by poorer women that have no access of such services in their particular country (Shetty and Vasanthi, 2019).During 1976 microfinance loan was started to overcome poverty and particularly empowered to women in the poorest society of Bangladesh through the Grameen Bank by Muhammad Younus. He was awarded Noble prize on this social contribution in the society, (Khandker and Samad, 2018).

The majority of the microfinance institutions (MFIs) pursue "hybrids" objective of outreach to deprived people (social 
performance), while protecting their costs and being monetarily sustainable (Financial performance). The conflict between financial sustainability in Microfinance institutions (MFIs) and social mission has often been the subject of news headlines of media while microcredit debtors have suicide after failing to return back their loan in the southeastern region of Pradesh India(Sainath, 2010), microfinance institutions have limited effectiveness to overcome poverty, the main cause of limited effectiveness of institutions are commercial and profit-oriented environment of Micro-finance institutions (MFIs), a series of studies by(Guérin et al., 2013)deeply examined the gradual materialistic approach of organizations in South India, Andhra Pradesh, and Mexico, providing vast countryspecific analysis that cause failure of developing inside expansion and consistency within microfinance institutions between their financial and social goals. These reflect some extent the situation in the Western Subprime Mortgage Crisis.

The practice of transparency, accountability and good governance by the manager which is the requirement of corporate governance. Corporate governance has vast topic for debate (Singh et al., 2018). The problem of study that various commercial microfinance institutions (MFIs) and loan providers charged a high rate of interest, application processing costs. Behind these circumstance such as high rate of interest, high cost of application processing fee, the poor borrower could not pay loan installment easily and faced problem by themselves and their family in real way. Very low and limited information has been delivered to loan seeker, renewal of loan forceful, selection standards are very poor, difficult to selling of loan, repayment collection strategies, abusive \& violent behavior cause low client-retention, limit consoling on usage of loan, negligence in polices are redefined, these are the characteristics of organizational structures, administrative system of commercial, homogenous and poor cost models of microfinance operation with inadequate social performance. Microfinance institutions have low transparency overall but larger microfinance institutions have greater transparency as compare to smaller microfinance institutions, (Tadele et al., 2018), nonprofit organizations have moved from original mission like social performance and its indicators such as empowerment, health and education of poor household. Social enterprise and duel objective organizations have 
change their mission statement into new direction (D'Espallier et al., 2017). This study is planned to answer the important question like, what is the impact of micro-finance on various dimensions of social performance?, what is impact of micro-finance loans on over all social performance?. At the last this research will be able to ascertain the moderating effect of ownership structure and transparency between relationship of micro-finance \& social performance. The objective of contemporaneous study is to empirically establish that whether the micro-finance has an impact of various dimensions of social performance. Other objective is to elaborate the impact of micro-finance loan on social performance and to explain the moderating effect of ownership structure and transparency between relationship of micro-finance and social performance. So far as we know that no study has explored loan transparency which is one of the basic needs of the microfinance institutions (MFIs) performance and social performance (Beisland et al., 2020). To fill this research gape consequences of microfinance institutions loan, and social performance have to be explored, whether strengthen of relationship of transparency and ownership structure associations between the micro finance loan and social performance. The large number of poor borrower of micro finance is illiterate and knowledge of level is very low regarding to financial service. Behind of these aspects, the transparency is more imperative for the micro finance customers and poor people (Thomas and Kumar, 2016), different forms of ownership react different changes in the regulatory environment. The non-bank financial institutions have transformed from NGOs, deviated from their poverty outreach goals in order to maximize profits. Micro finance institution consider an institutional "Hybrids" duelobjective i.e social mission and financial sustainability. According to the theory of microfinance that grant of financial facilities and goods can empower poor people and improve their education, health, as well as lifestyle and invest effectively in activities that generate an adequate financial return. Microfinance institutions relied on grants, and subsidies assistance to support public goals and overcome poverty as Grameen Bank was successful in achieving sustainability, improve efficiency and overcome to poverty among poor people (Islam, 2016). This study is significant for microfinance institutions, whether Non-government organization NGOs or 
commercial microfinance institutions, policymakers and academic scholars. It provides managerial implications that provision of transparent loan among microfinance customers can increase the performances of microfinance institutions to overcome poverty in developing economy(Bakar et al., 2019). By increasing investment in income-generating accomplishments and diversifying possible sources of income, access to funding of finance may help increase income in the long term, it may contribute in smooth consumption, reduce vulnerability due to disease, and access of micro finance my contribute to get better education, better health, it may contribute borrower housing. Moreover, access of loan may subsidize to improve the economic situation of women borrower. Lastly, Microfinance may have a positive spillover effect, so its impact exceeds the borrower's economic and social progress (Agbola et al., 2017). The scholars can simplify the results of this study at a wider level and can predict better usage microloan to overcome poverty, as well as support to social performance and lander's financial sustainability. As it is mentioned transparency of loan, ownership structure and social performance attracted the academics at the highest level and they can more expand this literature in a different direction. This study has highlighted that environmental factor when combined with this model, will also be an interesting area for future research.

\section{Hybrid of Micro Finance Institutions (MFIs)}

Microfinance institutions have made loan services as a historical struggle to find sufficient capital to fund their operation. A microfinance institution is a financial institute to provide loan services to microenterprise in developing the market in the context of social mission and overcome scarcity because poor people have no any valuable asset to use it as surety for loaning purposes. Without of surety commercial microfinance institutions are not offered to loan. Micro finance institutions (MFIs) have massive potential tool against scarcity. Based on this massive tool poor people can change their life style and living status. One famous scale of social benefit accomplished by micro finance institution s are the deepness of outreach, which shows the volume of loan to "poorer" deprived people. Usually, Micro institutions supporters are believed 
that significant association between micro finance and poverty alleviation. Even with enhanced study methods that is randomized control experiments, the subsidiary proof for such a belief is silent lacking (Banerjee et al., 2015; Karlan et al., 2018).

The Social Performance Task Force (SPTF) described that social performance is the effective integration of an organization. Social mission is recognized social value serves a large number of deprived people, refining the quality and suitability of financial services, facilitated to patrons with benefit and enhancing the social performance of microfinance institutions. MFIs main objective is to enhance social performance. The various tool have been devolved to support microfinance and measure to social performance. The social imprint is neither a social goal nor a measure of social performance, the microfinance institutions as a core feature of a hybrid organization that should be observable over multiple periods. Hence, once we consider the relationship between dual goals over time, important differences between for-profit and non-profit micro finance institutions may become apparent (Ang et al., 2016;Bauwens et al., 2019)

\section{Financial Performance of Micro Finance Institution}

Microcredit is a key parameter for the 21 st century's socioeconomics expansion. Microfinance was started in 1970 as a nonprofit institution such as Bank of Grameen Bangladesh, the microfinance business gradually diversifies in microfinance commercialization. Their process was natural significances for significant net income and fulfill to ample space of market of microfinance. The MFIs follows to welfare logic may tolerate relatively low effectiveness to try to expand outreach, while microfinance institution follows the logic of commercial to peruse high profitability than to expand outreach. And they found that the relationship between microfinance institution profitability and outreach inverted in the shape of U. Poor families in developing economies are away from formal financial systems. However, access to financials are essential for deprived people because this assistance can help them smooth their consumption, develop business occasions and enhance their presences in the ceremonial economy (Collins et al., 2009). Since the late 1970s, in emerging 
economies, the poor people have increased access to monetary services provided by microfinance institutions particularly since the 1990s, microfinance machines show significant growth in providing financial services to a deprived household (Reed and Maes, 2013). Microcredit helps emerging socio-economic circumstances of the derived poor people and has various clients, provided the millions and billions of dollars in financing micro businessperson since last few decades. A vital role of microcredit to overcome poverty, microcredit has attracted widespread attention from policymaker and academics researcher. The large number of the program of microfinance are dependent on donor subside still to fulfill high cost and derived bowers to deposit a high rate of interest called as poverty penalty (Gutiérrez-Nieto et al., 2017).

\section{Social Performance of Micro Finance Institutions}

According to (Gupta and Mirchandani, 2019) socially-oriented microfinance institutions have a higher percentage of poor women customer and greater customer outreach as compared to commercially oriented microfinance institutions. Further he investigated that socially-oriented microfinance institution and cooperative/credit union has revealed better social performance. The social performance measured in contexts of deeper outreach led to better financial performance. The microcredit supports to poor people and invest in dynamic activities, which are ultimately leads to increase income, consumption levelling, and developments in health, improvement in education, and empowerment of women. Microfinance outreach demonstrates that the MFIs can shelter a wider range of areas or serve more and greater number of poor individuals. Various determinates have been probed to study microfinance institution outreach. Most commonly parameters of depth and breadth outreach are used in empirical research. The depth of outreach is society's emphasis on the net benefits of specific customers. According to welfare theory, depth is the importance of customers in social welfare function. The breadth of poverty depends on the level of donation, a wide-range self-sustainable organization may attract as many poor people as possible povertyoriented organizations with a narrow scope (Nidarr et al., 2019). 
Throughout the history of human culture and society, as to expend of society and grew of culture day by day men-maintained positions power. Nowadays, a huge percentage of females are facing the problem in various domains including education, intra-household domination and political representation due to social strands and norms worldwide that inspires status differences for example (Armendáriz and Morduch, 2010) gender inequality was seen shown lower-income people and societies. Gender inequality was supported by the Gender Inequality Index as the statistically which is endorsed by the United Nations development program (UNDP, 2014).

The women of developing countries are poorest in the various parts of society. Gender can be used as an indicator to assess of loan, various commercial financial institutions do not want to provide loans to women because they have thought about the woman that does not control family income as compared to men. The women empowerment is an away from the condition of disempowerment and choice (Malhotra et al., 2002). According to different literature, the women's empowerment has been studied as a multidimensional concept which contains a variety of facets like freedom in life and gender believes, family supporting, feelings and social network, power of bargaining and women's participation in labor force. There are different aspects of women empowerment can be characterized in different dimensions which is personal, social empowerment and relational for example(Huis et al., 2017)own empowerment includes features of empowerment pertain to the specific self, such as self-efficacy, or sensitivity of individual agency. Concerning the relationship, the level of empowerment women is indicated by relational empowerment such as marriage, household, barging power as well as facets of association quality for example freedom of time, freedom of movement and initiate life partner violence.

\section{Transparency in Micro Finance}

Transparency is the main character in microfinance loans. It plays a vital role among the donors to build the association trust with microfinance institutions, whereas, profit providing institutions of public goods have to need to establish trust with stakehold ers as well as with shareholder. 
Transparency is basically the accessibility of information about all actors within the industry, such as the principle of the firm, agents and stakeholders. Several components of transparency to performed performance of transparency such as financial disclosures and governance. Financial transparency reflects the timeliness of financial disclosure and the quality of audits, as well as the interpretation and dissemination of intermediaries. Investors and other persons of the firm use governance disclosure to hold officials. Therefore, governance exposes include the identity of major shareholders, compensation, and equity of senior staff and directors. The performance transparency to understand as a tool that describes employee performance metrics, especially for customers, Bushman et al (2006).

Transparency creates a significant positivity between common people and the public of general public which in the move to fosters the development of trust. Whereas a number of researcher believe that transparency \& trust both are positively related to each other . According to ("Karlan, Osman, and Zinman 2018) described that the micro finance institutions (MFIs) are facing various operational problem and challenges, moreover, on the basis of randomized controlled experiment that loan officer have very limited ability. $\mathrm{He}$ did multiple mistakes when shortlisting and selecting the individuals for provision of micro finance loan. The Loan officers did not grant to more deprived people and loan have been granted to low performing people instead of deprived people and performing group. Further he recommended in their study that loan officer should need more assist to poor people on the actual basis.

\section{Ownership Structure in Micro Finance Institution}

Ownership is a key function of the governance system within the microfinance institutions and ultimately determines the performance of microfinance institutions (MFIs) (Campion, 1998). There are various ownership structures are an exit in the microfinance industry, i.e Banks, Non-bank financial institution, credit unions, and Non-government organizations. Non-bank financial institutions allocate the excess profit to their shareholders through unlike banks, non-bank financial institutions are legally restricted in the range of services, they can offer (for example, some people are unable to provide savings account. Credit cooperatives 
are non-profit organizations and controlled by a member. The profit is distributed among the members by the non-government organization. The non-government organization is a Non-profit organization characterized by non-distribution constraint.

Although all types of ownership of microfinance institutions are the social and financial motive, their relative weights vary by the sort of microfinance institutions (MFIs). As a shareholder firm, non-bank financial institutions and commercial banks are described their financial goals, non-governmental organizations and cooperatives pay more attention to the objective of society. The organizations are served to poorer customers through non-government organizations. The most important issue in the microfinance studies is the trade-off between financial and social performance and which one institution is survived among the financial and social performance. It may be the extent to which microfinance institutions (MFIs) are trying to reduce scarcity amongst the poor people, financial performance may be the goal that microfinance institutions (MFIs) are trying to achieve better customers borrow money (Simonsen, 2016)). These two goals are often thought this is contradictory because financial and social goals are discovered to have swapped the cost of lending to the poor, a large number of microfinance institutions are thought at the same time financial and social goals. The duality of the goal makes organizational governance is more difficult than an organization with a single goal. Various researchers pointed out that Non-Government organization (NGOs) type and Microfinance Institutions (MFIs) are cost control and acquisition finance and better governance. The NGOs are not paying much attention to high profitability, such types of microfinance organizations are not prioritized financial performance, but their main objective is the social performance, support to poor people, empowering to women, education and clean water. On another side, Bank-type microfinance institutions (BMFIs) are more associated with attracting better customers. Bank-type microfinance institutions are paying more attention to financial performance, high profitability instead of social performance.

Conceptual Model 


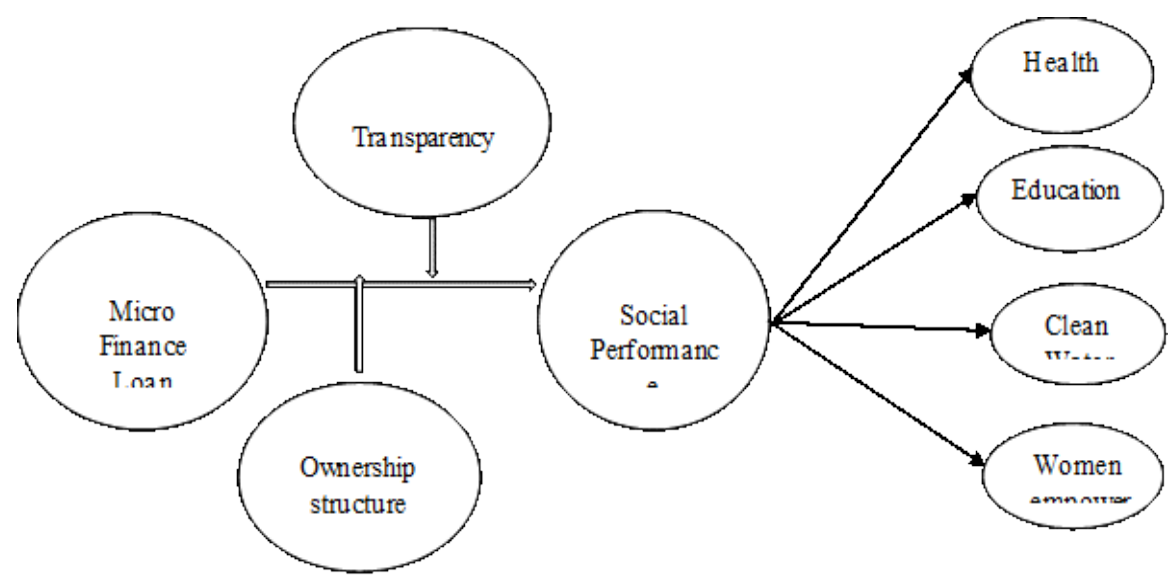

The above figure shows that microfinance loan is used as an independent variable and social performance is used as a dependent variable. Heath, Education, Clean Water and Women-empowerment are indicators of social performance. Ownership structure can be influenced microfinance institution and its social performance, microfinance institution social performance differs rendering to their ownership nature. transparency is the degree to which an entity is revealed information about its own decision-making processes, procedures, features and performance (Gerring and Thacker, 2004).Therefore, transparency and ownership structure used as a moderating variable between the microfinance and social performance. According to agency theory, focused ownership makes traditional principal-agent conflicts. In addition to conflicts between major shareholders and minority shareholders(Ginglinger and L'her, 2006). However, in microfinance, there is also conflicts between those who provide loan with social motive (such as noncommercial investments and donations) and those who provide commercial funds. And according to the theory of microfinance that grant of financial facilities and goods can empower poor people and improve their education, health, as well as lifestyle and invest effectively in activities that generate an adequate financial return. Microfinance institutions relied on grants, donations and subsidies assistance to support social goals and overcome poverty (Yunus 2007), for example in 1980 Grameen Bank was successful in 
achieving sustainability, improve efficiency and overcome to poverty among poor people.

Whereas transparency means $=\quad$ Distribution and process loan among customers with honesty and fair manners.

Micro Finance means $=$

It is the category of financial services for individual, small businesses who limited access to conventional banking.

Ownership Structure mean $=$ Commercial and noncommercial micro finance-institution Social Performance means $=$

outreach of poor people through education, healthcare, clean water and women empowerment in other words microfinance institutions can

\section{Hypothesis} pursue their original mission.

$\mathrm{H} 1_{0}$ : Micro-finance Loan has not significant influence on social performance.

$\mathrm{H} 1_{\mathrm{a}}$ : Micro-finance Loan has significant influence on social performance.

$\mathrm{H} 2_{0}$ : Micro Finance Loan has not significant influence on various dimensions of social performance i.e Health, Education, Clean Water and Women empowerment.

$\mathrm{H} 2_{\mathrm{a}}$ : Micro Finance Loan has significant influence on various dimensions of social performance i.e Health, Education, Clean Water and Women empowerment.

$\mathrm{H}_{3}$ : Moderating impact of transparency and ownership structure have not significant among the micro finance loan and social performance.

$\mathrm{H}_{\mathrm{a}}$ : Moderating impact of transparency and ownership structure have significant among the micro finance loan and social performance. 


\section{Data Analysis}

In smart PLS-SEM, the result can be obtained through different techniques (Jr et al., 2014). There are two different techniques were used to obtain an empirical result in a contemporaneous study. We applied the first technique is the PLS algorithm to check indicator reliability, significant of items and path coefficient of the construct. The second technique applied to bootstrap to obtain the empirical result of t-statistics and standard error which can be used to check the significance of the path relationship among the unobserved/construct variable. Figure 1 reveals the estimated model of the unobserved/latent variable of the contemporaneous study. The latent variable cannot directly be measured are included in the path model as a circle. Variables can be measured through items that are called indicators of the variable.

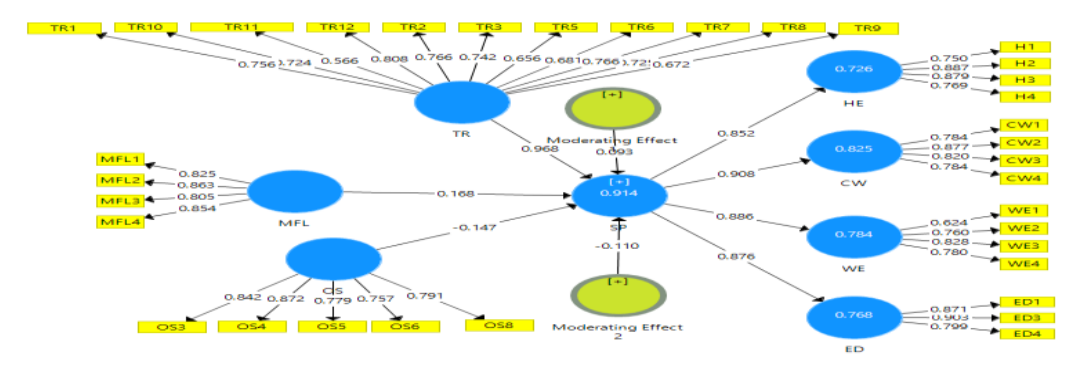

Fig estimation

The existing study estimated model is above, all variables are in round shape that is called a latent variable or constructs. The latent variables were measured through square shape indicators. Value among arrows of latent variables is revealing the path coefficient relationship. Value among items are showing factor loading of the particular item.

In the above model, social performance is a second-order construct which was measured through four selected dimensions i.e Health, Clean Water, Education and women empowerment. These dimensions are indicators of the construct of social performance. Therefore, path coefficient value of the dimensions of social performance will consider second-order construct factor loading(Hair Jr et al., 2016).Micro Finance Loan is the exogenous variable or independent variable, Social performance is the endogenous variable or dependent variable. Transparency and 
Perennial Journal of History, Vol II. No. II

ownership structure is moderating variable. PLS algorithm was used on254 respondents for estimation of model.

\section{Table No 01 : Reliability \& validity}

\begin{tabular}{|c|c|c|c|c|c|}
\hline Construct & $\begin{array}{l}\text { Cronbac } \\
\text { h's } \\
\text { Alpha }\end{array}$ & $\begin{array}{l}\text { Compos } \\
\text { ite } \\
\text { Reliabili } \\
\text { ty }\end{array}$ & $\begin{array}{l}\text { Averag } \\
\text { e } \\
\text { extract } \\
\text { ed } \\
\text { (AVE) } \\
\end{array}$ & $\begin{array}{l}\text { Indicat } \\
\text { or }\end{array}$ & $\begin{array}{l}\text { Factor } \\
\text { Loadi } \\
\text { ng }\end{array}$ \\
\hline \multirow{8}{*}{ Clean Water } & \multirow{8}{*}{0.833} & \multirow{8}{*}{0.889} & \multirow{8}{*}{$\begin{array}{l}0.66 \\
8\end{array}$} & CW & 0.78 \\
\hline & & & & 1 & 4 \\
\hline & & & & CW & 0.87 \\
\hline & & & & 2 & 7 \\
\hline & & & & CW & 0.82 \\
\hline & & & & 3 & 0 \\
\hline & & & & CW & 0.78 \\
\hline & & & & 4 & 4 \\
\hline \multirow{5}{*}{ Education } & \multirow{5}{*}{0.821} & \multirow{5}{*}{0.894} & \multirow{5}{*}{$\begin{array}{l}0.73 \\
7\end{array}$} & & 0.87 \\
\hline & & & & EDI & 1 \\
\hline & & & & ED3 & 0.90 \\
\hline & & & & & 70 \\
\hline & & & & ED4 & 9 \\
\hline \multirow{7}{*}{ Health } & \multirow{7}{*}{0.841} & \multirow{7}{*}{0.894} & \multirow{7}{*}{$\begin{array}{l}0.67 \\
9\end{array}$} & HE1 & 0.75 \\
\hline & & & & HE & 0 \\
\hline & & & & HE2 & 0.88 \\
\hline & & & & & \\
\hline & & & & HE3 & $\begin{array}{l}0.81 \\
9\end{array}$ \\
\hline & & & & LE4 & 0.76 \\
\hline & & & & ПГ4 & 9 \\
\hline \multirow{8}{*}{$\begin{array}{l}\text { Micro } \\
\text { Loan }\end{array}$} & \multirow{8}{*}{0.858} & \multirow{8}{*}{0.903} & & MFL & 0.82 \\
\hline & & & & 1 & 5 \\
\hline & & & 0.70 & MFL & 0.86 \\
\hline & & & 1 & 2 & 3 \\
\hline & & & & MFL & 0.80 \\
\hline & & & & & 5 \\
\hline & & & & MFL & 0.85 \\
\hline & & & & 4 & 4 \\
\hline
\end{tabular}




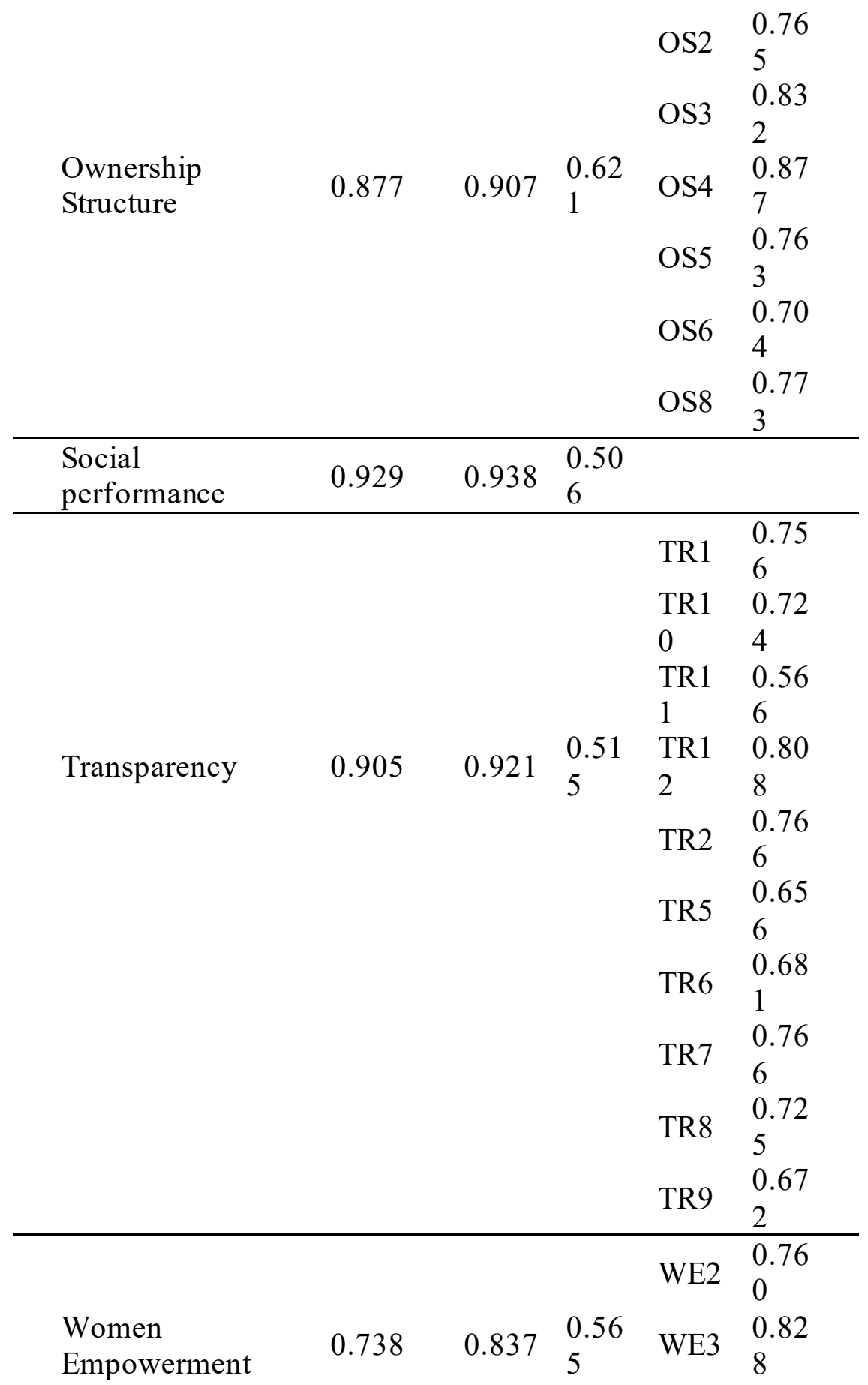




\section{Reliability and Validity}

Evaluation of measurement model and internal consistency reliability are checked through the composite reliability. Internal consistency reliability is checked through Cronbach's Alpha in smart PLS-SEM. The threshold value should be 0.65 and 0.95 which is satisfactory and considered as a suitable Cronbach's alpha. In the above table 1 revealed that all value of composite reliability and Cronbach's alpha is more than 0.65 . Therefore, there is no problem with composite reliability. Convergent validity explains the model's ability and variance of the indicator. This is used for the reliability of data and reliability of the indicator (Jr et al., 2014). The outer loading value of the indicator should be greater than 0.70 and if the values of the outer loading exit from 0.40 to 0.70 should be removed. There is no problem with convergent validity. If it has contributed to increasing composite reliability and AVE and another side the indicator value less than 0.40 should be removed always.

All factor loading of all indicators is greater than 0.70 and all construct AVE is greater than 0.5 therefore, these factor loading can be considered appropriate. The average value of AVE is 0.5 and value is less than 0.5 indicates that the errors in the project are on average larger than the variance of the constructed interpretation. The result of the above table shows that exiting data and model no problem with convergent validity because the all value of AVE is greater than 0.5 .

\section{Discernment Validity}

In PLS-SEM, Fornell-Larker Criterion (1981) common and rational approach is applied to check discernment validity and another approach is cross loading examination can be used to assess discernment validity. Discriminate validity referred to the extent to which the constructs actually differ from each other empirically. It also measures the degree of difference between overlapping in the construct. By observing cross-loading, the factor indicator of the allocate construct should be higher than all loadings of other 
constructs condition that the cutoff value is higher than 0.70 (Hair et al., 2011)(Hair Jr et al., 2016).

Table 2: Cross Loading

\begin{tabular}{|c|c|c|c|c|c|c|c|c|}
\hline $\begin{array}{l}\text { Item } \\
\text { s }\end{array}$ & $\begin{array}{l}\text { Clean } \\
\text { Water }\end{array}$ & $\begin{array}{l}\text { Educatio } \\
\mathrm{n}\end{array}$ & $\begin{array}{l}\text { Healt } \\
\text { h }\end{array}$ & $\begin{array}{l}\text { Micro } \\
\text { Loan }\end{array}$ & Finance & $\begin{array}{l}\text { Ownership } \\
\text { Structure }\end{array}$ & $\begin{array}{l}\text { Transparenc } \\
\mathrm{y}\end{array}$ & $\begin{array}{l}\text { Wealt } \\
\text { h }\end{array}$ \\
\hline CW1 & 0.784 & 0.503 & 0.598 & 0.440 & & 0.514 & 0.675 & 0.629 \\
\hline CW2 & 0.877 & 0.585 & 0.700 & 0.608 & & 0.627 & 0.728 & 0.586 \\
\hline CW3 & 0.820 & 0.644 & 0.627 & 0.512 & & 0.608 & 0.702 & 0.491 \\
\hline CW4 & 0.784 & 0.537 & 0.553 & 0.408 & & 0.530 & 0.736 & 0.617 \\
\hline ED1 & 0.591 & 0.871 & 0.522 & 0.596 & & 0.700 & 0.792 & 0.768 \\
\hline ED3 & 0.657 & 0.903 & 0.534 & 0.624 & & 0.782 & 0.761 & 0.735 \\
\hline ED4 & 0.536 & 0.799 & 0.504 & 0.762 & & 0.830 & 0.676 & 0.610 \\
\hline HE1 & 0.505 & 0.339 & 0.750 & 0.329 & & 0.393 & 0.430 & 0.295 \\
\hline HE2 & 0.552 & 0.458 & 0.887 & 0.428 & & 0.464 & 0.537 & 0.487 \\
\hline HE3 & 0.676 & 0.560 & 0.879 & 0.521 & & 0.559 & 0.612 & 0.530 \\
\hline HE4 & 0.728 & 0.587 & 0.769 & 0.617 & & 0.652 & 0.762 & 0.651 \\
\hline $\begin{array}{l}\text { MFL } \\
1\end{array}$ & 0.533 & 0.721 & 0.476 & 0.825 & & 0.862 & 0.722 & 0.707 \\
\hline $\begin{array}{l}\text { MFL } \\
2\end{array}$ & 0.515 & 0.676 & 0.509 & 0.863 & & 0.780 & 0.629 & 0.572 \\
\hline $\begin{array}{l}\text { MFL } \\
\mathbf{3}\end{array}$ & 0.436 & 0.512 & 0.490 & 0.805 & & 0.724 & 0.512 & 0.382 \\
\hline $\begin{array}{l}\text { MFL } \\
4\end{array}$ & 0.528 & 0.618 & 0.506 & 0.854 & & 0.743 & 0.651 & 0.530 \\
\hline OS2 & 0.635 & 0.880 & 0.547 & 0.614 & & 0.765 & 0.759 & 0.736 \\
\hline OS3 & 0.539 & 0.789 & 0.480 & 0.744 & & 0.832 & 0.671 & 0.587 \\
\hline OS4 & 0.545 & 0.744 & 0.492 & 0.833 & & 0.877 & 0.731 & 0.678 \\
\hline OS5 & 0.485 & 0.645 & 0.482 & 0.828 & & 0.763 & 0.597 & 0.558 \\
\hline OS6 & 0.407 & 0.473 & 0.438 & 0.770 & & 0.704 & 0.481 & 0.384 \\
\hline OS8 & 0.637 & 0.604 & 0.573 & 0.669 & & 0.773 & 0.803 & 0.612 \\
\hline TR1 & 0.602 & 0.586 & 0.487 & 0.647 & & 0.758 & 0.756 & 0.570 \\
\hline TR10 & 0.584 & 0.735 & 0.425 & 0.569 & & 0.655 & 0.724 & 0.760 \\
\hline TR11 & 0.384 & 0.574 & 0.443 & 0.443 & & 0.492 & 0.566 & 0.736 \\
\hline TR12 & 0.602 & 0.878 & 0.530 & 0.621 & & 0.736 & 0.808 & 0.811 \\
\hline TR2 & 0.556 & 0.599 & 0.518 & 0.639 & & 0.711 & 0.766 & 0.596 \\
\hline TR3 & 0.512 & 0.583 & 0.439 & 0.634 & & 0.709 & 0.742 & 0.562 \\
\hline TR5 & 0.781 & 0.483 & 0.681 & 0.512 & & 0.520 & 0.656 & 0.581 \\
\hline TR6 & 0.789 & 0.596 & 0.669 & 0.457 & & 0.542 & 0.681 & 0.494 \\
\hline TR7 & 0.792 & 0.588 & 0.550 & 0.461 & & 0.586 & 0.766 & 0.627 \\
\hline TR8 & 0.706 & 0.504 & 0.622 & 0.473 & & 0.546 & 0.725 & 0.623 \\
\hline TR9 & 0.446 & 0.677 & 0.308 & 0.547 & & 0.621 & 0.672 & 0.722 \\
\hline WE1 & 0.670 & 0.460 & 0.623 & 0.430 & & 0.498 & 0.695 & 0.624 \\
\hline
\end{tabular}


Perennial Journal of History, Vol II. No. II

\begin{tabular}{llllllll} 
WE2 & 0.420 & 0.657 & 0.319 & 0.525 & 0.599 & 0.657 & $\mathbf{0 . 7 6 0}$ \\
WE3 & 0.571 & 0.733 & 0.430 & 0.557 & 0.662 & 0.722 & $\mathbf{0 . 8 2 8}$ \\
WE4 & 0.443 & 0.612 & 0.457 & 0.484 & 0.540 & 0.608 & $\mathbf{0 . 7 8 0}$ \\
\hline
\end{tabular}

\section{Fornell-Larcker Criteria for Discriminant validity}

The Fornell-Larcker Criteria were used for evaluating of discernment validity. This test method has compared the square root of average variance extracted (AVE) with latent variable/construct correlation. The latent variable/ construct will explain the variance of own indicator rather than the variance of other latent constructs. Consequently, the square root of each construct's AVE will have a greater than the correlation with other latent constructs ( $\mathrm{Jr}$ et al, 2014)

Table 3: Fornell-Larcker criteria

\begin{tabular}{lllllllll}
\hline & CW & ED & HE & MFL & SP & OS & TR & WE \\
\hline CW & $\mathbf{0 . 8 1 7}$ & & & & & & & \\
ED & 0.695 & $\mathbf{0 . 8 5 9}$ & & & & & & \\
HE & 0.760 & 0.605 & $\mathbf{0 . 8 2 4}$ & & & & & \\
MFL & 0.605 & 0.763 & 0.591 & $\mathbf{0 . 8 3 7}$ & & & & \\
SP & 0.908 & 0.877 & 0.852 & 0.741 & $\mathbf{0 . 7 1 1}$ & & & \\
OS & 0.699 & 0.894 & 0.642 & 0.933 & 0.846 & $\mathbf{0 . 7 8 8}$ & & \\
TR & 0.869 & 0.867 & 0.728 & 0.759 & 0.953 & 0.870 & $\mathbf{0 . 7 1 8}$ & \\
WE & 0.709 & 0.823 & 0.615 & 0.667 & 0.886 & 0.769 & 0.899 & $\mathbf{0 . 7 5 2}$ \\
\hline
\end{tabular}

*The diagonal of square root of AVE.

The table 3 revealed that the value in the first row of the representative construct is the square root of the AVE and the cross values of correlation values to with another construct, which is highlighted in bold form. The square root of the AVE construct Micro Finance Loan value 0.817, this value is greater than the correlation value. The same approach was applied to the reset of constructs and indicators. There is no issue regarding discernment validity.

\section{Evaluation Multi-co-linearity}

Rule of thumb regarding problematic multi-co-linearity is that variance inflation factor VIF coefficient is not more than 4.0. Whereas various researcher applied 5.0 cut off because it is more 
lenient, value less than 10 reveal the absence of multi-colinearity(Anwar et al., 2018). Therefore, table 5 is revealing that multi-co-linearity less than 0.5 . There is no multi-co-linearity problem among the item and latent variables.

Table 4: outer variance inflation factor VIF value

\begin{tabular}{|c|c|c|c|c|c|c|c|c|c|c|c|c|c|}
\hline & $\begin{array}{l}\text { VI } \\
\text { F }\end{array}$ & & $\begin{array}{l}\text { VI } \\
\text { F }\end{array}$ & & $\begin{array}{l}\text { VI } \\
\text { F }\end{array}$ & & $\begin{array}{l}\text { VI } \\
\text { F }\end{array}$ & & $\begin{array}{l}\text { VI } \\
\text { F }\end{array}$ & & $\begin{array}{l}\text { VI } \\
\text { F }\end{array}$ & & $\begin{array}{l}\text { VI } \\
\text { F }\end{array}$ \\
\hline TR & 3.6 & $\mathbf{O}$ & 1.8 & $\mathbf{C}$ & 3.1 & $\bar{E}$ & 2.0 & H & 1.6 & MF & 1.8 & $\mathbf{W}$ & 2.5 \\
\hline 1 & 45 & S2 & 70 & W1 & 85 & D1 & 89 & E1 & 41 & L1 & 21 & E1 & 00 \\
\hline TR & 2.4 & O & 2.5 & C & 3.6 & $\mathbf{E}$ & 3.2 & H & 3.1 & MF & 2.3 & W & 1.6 \\
\hline 10 & 71 & S3 & 15 & W2 & 08 & D1 & 52 & E2 & 12 & L2 & 90 & E2 & 38 \\
\hline TR & 2.0 & 0 & 3.2 & C & 2.1 & $\mathbf{E}$ & 3.5 & H & 2.9 & MF & 1.8 & $\mathbf{W}$ & 1.7 \\
\hline 11 & 72 & S4 & 61 & W3 & 52 & D3 & 57 & E3 & 03 & L3 & 98 & E3 & 11 \\
\hline TR & 3.4 & O & 2.1 & C & 1.7 & $\mathbf{E}$ & 1.5 & H & 1.4 & MF & 2.3 & W & 2.4 \\
\hline 12 & 04 & S5 & 21 & W4 & 01 & D4 & 72 & E4 & 48 & L4 & 71 & E4 & 30 \\
\hline TR & 3.8 & 0 & 1.9 & & & & & & & & & & \\
\hline 2 & 37 & S6 & 80 & & & & & & & & & & \\
\hline TR & 3.3 & O & 1.8 & & & & & & & & & & \\
\hline 3 & 00 & S8 & 89 & & & & & & & & & & \\
\hline TR & 2.2 & & & & & & & & & & & & \\
\hline 5 & 37 & & & & & & & & & & & & \\
\hline TR & 2.2 & & & & & & & & & & & & \\
\hline 6 & 86 & & & & & & & & & & & & \\
\hline TR & 2.5 & & & & & & & & & & & & \\
\hline 7 & 82 & & & & & & & & & & & & \\
\hline TR & 2.6 & & & & & & & & & & & & \\
\hline 8 & 44 & & & & & & & & & & & & \\
\hline TR & 2.0 & & & & & & & & & & & & \\
\hline 9 & 94 & & & & & & & & & & & & \\
\hline
\end{tabular}

\section{Path Analysis}

Table 5: Path analysis direct effect

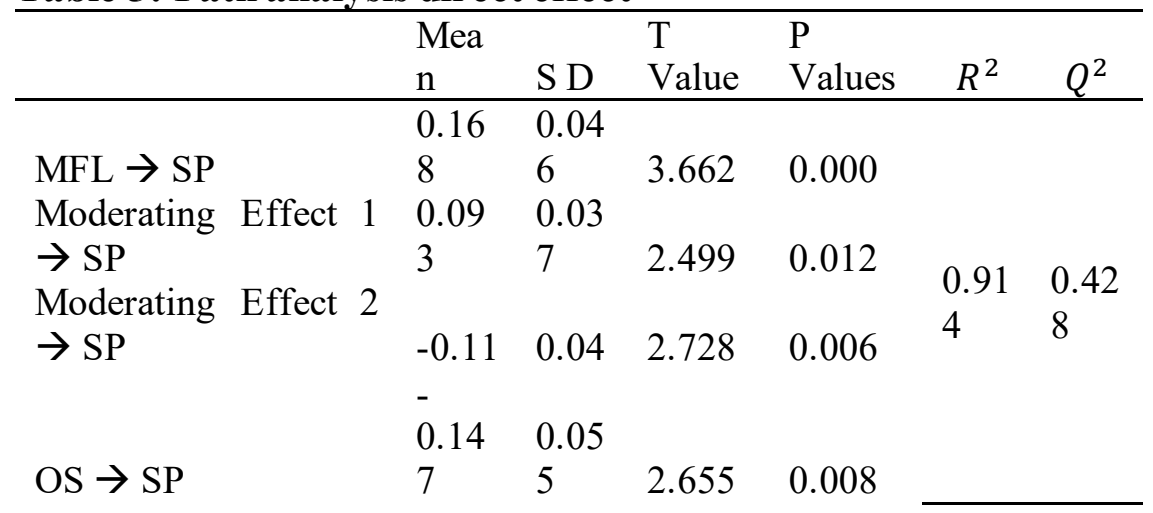




\begin{tabular}{|c|c|c|c|c|c|c|}
\hline $\mathrm{TR} \rightarrow \mathrm{SP}$ & $\begin{array}{l}0.96 \\
8\end{array}$ & $\begin{array}{l}0.02 \\
9\end{array}$ & $\begin{array}{l}33.07 \\
5\end{array}$ & 0.000 & & \\
\hline & 0.90 & & 88.34 & & 0.82 & \\
\hline \multirow[t]{2}{*}{$\mathrm{SP} \rightarrow \mathrm{CW}$} & 8 & 0.01 & 6 & 0.000 & 5 & 0.52 \\
\hline & 0.87 & 0.01 & 46.99 & & 0.76 & 0.53 \\
\hline \multirow{2}{*}{$\mathrm{SP} \rightarrow \mathrm{ED}$} & 6 & 9 & 7 & 0.000 & 8 & 8 \\
\hline & 0.85 & 0.01 & 54.83 & & 0.72 & 0.45 \\
\hline $\mathrm{SP} \rightarrow \mathrm{HE}$ & $\begin{array}{l}2 \\
0.88\end{array}$ & $\begin{array}{l}6 \\
0.01\end{array}$ & $\begin{array}{l}3 \\
65.04\end{array}$ & 0.000 & $\begin{array}{l}6 \\
0.78\end{array}$ & 4 \\
\hline $\mathrm{SP} \rightarrow \mathrm{WE}$ & 6 & 4 & 9 & 0.000 & 4 & 0.41 \\
\hline
\end{tabular}

Table6: Indirect effect

\begin{tabular}{lllll}
\hline & Mean & SD & T Value & P Values \\
\hline MFL -> CW & 0.153 & 0.042 & 3.663 & 0.000 \\
MFL -> ED & 0.147 & 0.04 & 3.645 & 0.000 \\
MFL -> HE & 0.143 & 0.039 & 3.663 & 0.000 \\
MFL -> WE & 0.149 & 0.041 & 3.649 & 0.000 \\
\hline
\end{tabular}

In Smart PLS, the relationships between constructs can be determined by examining their path coefficients and related $t$ statistics via the bootstrapping. From the above-estimated model, Micro Finance Loan is the Independent variable, Social performance is a dependent variable which is directly measured through the second-order construct. Transparency and ownership structure are the moderating variables, the significance level is observed through bootstrapping, according to as illustrated results tabulated in Table 5 that the impact of micro finance loan on social performance is showing significant impact as evident fromP-value is 0.000 . The moderating effect of ownership structure is significantly effect on social performance as the $p$ value is 0.001 and moderating effect of transparency is also significant impact on social performance as evident from P-value is 0.000 . However, moderation test is analyzed by creating an interacting variable in smart PLS and its effect is examined through PLS algorithm that the interacting variable ownership is revealing negative significant effect on social performance and transparency is revealing the positive significant impact on social performance. On the basis of above result, transparency and ownership structure are mediating as partially between the microfinance loan and social performance. 
Table 6 results are revealing the indirect impact that micro finance loan is significantly impact on the social performance and on its various dimensions i.e Education, Health Clean Water and Women empowerment as evident from the p-value is less than 0.05 .

\section{Coefficient of Determination $\boldsymbol{R}^{\mathbf{2}}$}

The predictive accuracy of model is measure d through $R^{2}$ because which is showing a combined effect on variable of endogenous. The rule of them for acceptance of $R^{2}$ value should be $0.25,0.50,0.75$, week level, moderate and strong respectively are showing predictive accuracy of model (Henseler et al., 2014). In this study, three constructs Micro finance loan, Transparency and ownership structure can jointly describe $R^{2} 91.4 \%$ of the variance of the endogenous construct social performance. Over all $R^{2}$ showing accuracy of our model is strong.

\section{Predictive Relevance $\boldsymbol{Q}^{\mathbf{2}}$}

The predictive relevancy of model is measured through $Q^{2}$ because which suggest a good predictive relevance of model when the value of $Q^{2}$ is greater than zero (Chin 1998), therefore, table 5 showing value of $Q^{2}$ is greater than zero. The model predictive relevance is good because $Q^{2}$ value of endogenous variable is larger than zero.

\section{Discussion}

After a detailed and deep analysis of data, the study is showing that transparency is the main factor and it is necessary for micro finance loans borrowers and especially for micro-finance industry. In this study, transparency is playing significant moderating role among the micro finance loan and social performance. Our results are quite similar to the study of (Augustine, 2012) wherein he described that transparency brings to information, processes, and services that create faith and relationship among microfinance organizations and their voters, patrons, employees, customers or stockholders for example(Tadele et al., 2018) stated that transparency of micro finance institutions (MFIs) as compared to financial development is low. Larger institutions of micro finance have greater transparency as compared to smaller micro finance institution.

Second ownership structure is also playing significant moderating influence among the micro finance loan and social performance, the result of this study quit similar to (Barth et al., 2012) that the ownership referred by the composition. In exiting composition 
included non-government organizations (NGOs) and non-bank financial institutions (NBFIs). Beside, non-government organizations (NGOs) type micro finance institutions (MFIs) are reflect less concerned with high level of profitability, such types of micro finance institution are found to be less concerned with high profitability. Bank type institutions are preferred to financial performance of institutions and attracting to customers instead poor people (Amin et al., 2018)stated that nonprofit micro finance institutions (MFIs) have more capacity to support poor people, micro enterprises, small business and female barrowers. Therefore, profit based micro finance institutions (MFIs) could be learn from non-profit micro finance institutions (MFIs) for more effective socialism into the financial sustainability.

Micro finance loan is the significant influence in social performance and its various dimensions, the result consist with the study (Mort et al., n.d.), MFIs are providing financial support to the poor people who are away from formal financial institutions. Majority and various micro finance institutions focus on entrepreneurial credit of entrepreneur who needs of financial capital for business support and economic growth. According to (Helms, 2006) said microfinance is the powerful tool for poverty reduction.

\section{Contribution of Study}

After detail analysis, the exiting study has some originality or uniqueness that the moderating variable of loan transparency and ownership structure are examined the first time. The influence of microfinance loans on social performance and its various dimensions are not discussed before. The contemporaneous study contributes to expending the practical implication of microcredit theory which is beneficial for the poor people how poor people can get a loan from the microfinance institutions.

\section{Conclusion}

The purpose of this study is to check the performance of microfinance loan in the context of social performance and its various dimensions i.e health, education, clean water, and women empowerment. And test the moderating effect of loan transparency and ownership structure between micro-finance loan and social performance. Whereas, transparency and ownership structure is observed as an interacting variable which has the ability to strengthen the relationship between microfinance loan and social 
performance. All relationships including their casual relationships were observed through a sample of 350 individuals who are facilitated with microfinance loans for last 1-5 years. It was found through data analysis that the influence of microfinance loan on social performance and its various dimensions were significant and the moderating impact of transparency and ownership structure between the relationship of microfinance loan and social performance also significant.

The findings of this study show that provision of microloan is beneficial for the outreach of poor people, household and poor females in the emerging economy. In addition, transparency of loan develops a trust between microfinance lender and borrower. Whereas ownership structure create problem for the microfinance borrowers and poor people in emerging economy. 


\section{References}

1. Agbola, F.W., Acupan, A., Mahmood, A., 2017. Does microfinance reduce poverty? New evidence from Northeastern Mindanao, the Philippines. J. Rura1Stud. 50, 159-171.

2. Amin, W., Qin, F., Ahmad, F., Rauf, A., 2018. Ownership Structure and Microfinance Institutions' Performance: A Case of La tin America. Eur. Online J. Nat. Soc. Sci. 7, pp-127.

3. Amoako-Gyampah, K., Boakye, K.G., Adaku, E., Famiyeh, S., 2019. Supplier relationship management and firm performance in developing economies: A moderated mediation analysis of flexibility capability and ownership structure. Int. J. Prod. Econ. 208, 160-170.

4. Ang, A.X., Ja cob, G.H., Lam, S.-S., Zhang, W., 2016. The reciprocity of financial and social performance in social enterprises: Evidence from MFIs. Presented at the Proceedings of International Symposium on SocialEntrepreneurship 2016, p. 36.

5. Anwar, M., Zaman Khan, S., Ali Shah, S.Z., 2018. A Study of the Relationship Between Innovation and Performance Among NPOs in Pakistan. J. Soc. Serv. Res. 1-15.

6. Armendáriz, B., Morduch, J., 2010. The economics of microfinance. MIT press.

7. Augustine, D., 2012. Good practice in corporate governance: Transparency, trust, and performance in the microfinance industry. Bus. Soc. 51, 659-676.

8. Bakar, N.M., Rahman, R.A., Ibrahim, Z., 2019. Client protection and susta inable performance in microfinance institution. Int. J. Product. Perform. Manag.

9. Banerjee, A., Duflo, E., Glennerster, R., Kinnan,C., 2015. The miracle of microfinance? Evidence from a randomized evaluation. Am. Econ. J. Appl. Econ. 7, 22-53.

10. Barth, J.R., Lin, C., Wihlborg, C., 2012. Resea rch handbook on interna tional banking a nd governance. Edward Elgar Publishing.

11. Bauwens, T., Huybrechts, B., Dufays, F., 2019. Understanding the diverse scaling stra tegies of social enterprises as hybrid organizations: The case of renewable energy cooperatives. Organ. Environ. 1086026619837126.

12. Beisland, L.A., Djan, K.O., Mersland, R., Randøy, T., 2020. Measuring Social Performance in Social Enterprises: A Global Study of MicrofinanceInstitutions. J. Bus. Ethics 1-21.

13. Beisland, L.A., Mersland, R., Randøy, T., 2014. Transparency and disclosure in the globalmicrofinance industry: Implications for practice and policy makers. Oxf. Handb. Polit. Institutional Corp. Transpar. Oxf. Univ. Press N. Y. USA.

14. Bell, E., Bryman, A., Harley, B., 2018. Business research methods. Oxford university press. 
15. Bruton, G.D., Khavul, S., Cha vez, H., 2011. Microlending in emerging economies: Building a new line of inquiry from the ground up. J. Int. Bus. Stud. 42, 718-739.

16. Burgis, (2008 microfinance - Google Scholar [WWW Document], n.d. URL

https://scholar.google.com/scholar?hl=en\&as_sdt=0\%2C $5 \& \mathrm{q}=$ Burgis $\%$ $2 \mathrm{C}+\% 282008+$ microfinance $\& \mathrm{btnG}=\&$ oq $=$ Burgis $\% 2 \mathrm{C}+\% 282008 \% 29+$ micr(accessed 11.23.19).

17. Campion, A., 1998. Current Governance Practices of Microfinance Institutions: A Survey Summary. Microfinance Network.

18. Carter, D., Barker, T., 1994. Administrative guidance and control of police officer behavior: Policies, procedures, and rules. Police Deviance Third Ed. Cincinnati Ohio Anderson Publ. Co 13-28.

19. Chliova, M., Brinckmann, J., Rosenbusch, N., 2015. Is microcredit a blessing for the poor? A meta-analysis examining development outcomes and contextual considerations. J. Bus. Ventur. 30, 467-487.

20. Collins, D., Morduch, J., Rutherford, S., Ruthven, O., 2009. Portfolios of the poor: how the world's poor live on $\$ 2$ a day. Princeton University Press.

21. D’Espallier, B., Goedecke, J., Hudon, M., Mersland, R., 2017. From NGOs to banks: Does institutional transformation alter the business model of microfinance institutions? World Dev. 89, 19-33.

22. Ekpete, M.S., Iwedi, M., 2017. Fina ncial intermediation functions of microfinance banks in Nigeria: A vector a utoregressive and multivariate a pproach. Int. J. Econ. Financ. Model. 2, 7-24.

23. Gerring, J., Thacker, S.C., 2004. Political institutions and corruption: The role of unitarism and parliamentarism. Br. J. Polit. Sci. 34, 295-330.

24. Ginglinger, E., L'her, J.-F., 2006. Ownership structure and open market stock repurchases in France. Eur. J. Finance 12, 77-94.

25. Guérin, C., Reignier, J., Richard, J.-C., Beuret, P., Ga couin, A., Boulain, T., Mercier, E., Badet, M., Mercat, A., Baudin, O., 2013. Prone positioning in severe acute respiratory distress syndrome. N. Engl. J. Med.368,2159-2168.

26. Gupta, N., Mirchandani, A., 2019. Corporate governance and performance of microfinance institutions: recent global evidences. J. Manag. Gov. 1-20.

27. Gutiérrez-Nieto, B., Serrano-Cinca, C., Cuéllar-Fernández, B., FuertesCallén, Y., 2017. The Poverty Penalty and Microcredit. Soc. Indic. Res. $133,455-475$.

28. Hair, J.F., Ringle, C.M., Sarstedt, M., 2011 . PLS-SEM: Indeed a silver bullet. J. Mark. Theory Pract. 19, 139-152.

29. Hair Jr, J.F., Hult, G.T.M., Ringle, C., Sarstedt, M., 2016. A primer on partial least squares structural equation modeling (PLS-SEM). Sage publications.

30. Helms, B., 2006. Access for all: building inclusive fina ncial systems. The World Bank. 
31. Henseler, J., Dijkstra, T.K., Sarstedt, M., Ringle, C.M., Diamantopoulos, A., Straub, D.W., Ketchen Jr, D.J., Ha ir, J.F., Hult, G.T.M., Calantone, R.J., 2014. Common beliefs and reality about PLS: Comments on Rönkkö andEvermann(2013). Orga n. Res. Methods 17, 182-209.

32. Huis, M.A., Hansen, N., Otten, S., Lensink, R., 2017. A threedimensionalmodel of women's empowerment: Implications in the field of microfinance and future directions. Front. Psychol. 8, 1678.

33. Isla m, T., 2016. Microcredit and poverty alleviation. Routledge.

34. Jr, J.F.H., Sarstedt, M., Hopkins, L., Kuppelwieser, V.G., 2014. Partial lea st squares structural equation modeling (PLS-SEM). Eur. Bus. Rev. https://doi.org/10.1108/EBR-10-2013-0128

35. Karlan, D., Osman, A., Zinman, J., 2018. Dangers of a double-bottom line: A poverty targeting experiment misses both targets. National Burea uf Economic Research.

36. Karlan, D.S., Zinman, J., 2008. Credit elasticities in less-developed economies: Implications for microfinance. Am. Econ. Rev. 98, 1040-68.

37. Karlan, Osman, and Zinman (2018) - Google Scholar [WWW Document], n.d. URL https://scholar.google.com/scholar?hl=en\&as_sdt=0\%2C $5 \& \mathrm{q}=\operatorname{Karlan} \%$ $2 \mathrm{C}+$ Osman $\% 2 \mathrm{C}+$ and + Zinman $+\% 282018 \% 2 \overline{9} \& \mathrm{btnG}=\quad$ (accessed 11.9.19).

38. Khandker, S.R., Samad, H.A., 2018. Bangla desh's achievement in poverty reduction: The role of microfinance revisited, in: Economic and SocialDevelopment of Bangladesh. Springer, pp. 177-198.

39. Krenz, K., Gilbert, D.J., Mandayam, G., 2014. Exploring women's empowerment through "credit-plus" microfinance in India. Affilia 29, 310-325.

40. Malhotra, A., Schuler, S.R., Boender, C., 2002. Measuring women's empowerment as a variable in international development. Presented at the background paper prepared for the World Bank Workshop on Poverty and Gender: New Perspectives.

41. Morduch, J., 1998. Does microfinance really help the poor?: New evidence from flagship programs in Bangla desh. Research Program in Development Studies, Woodrow School of Public and ....

42. Mort, S., Weera wardena, G., Carnegie, J., n.d. K.(2003): Social Entrepreneurship: Towards Conceptualisation. Int. J. Nonprofit Volunt. Sect. Mark. 8, 76-88.

43. Nidarr, S.R., Febrianty, H.F., Anwar, M., Layyinaturrobaniyah, L., 2019. The Role of Microfinance Institutions on the Improvement of Community Social Welfare: The case on impacted persons in the development areas of Jatigede reservoir in Sumedang District, WestJava Indonesia. Presented at the 1 st International Conference on Economics, Business, Entrepreneurship, and Finance (ICEBEF 2018), Atlantis Press.

44. Park, H., Blenkinsopp, J., 2011. The roles of transparency and trust in the relationship between corruption and citizen satisfaction. Int. Rev. Adm. Sci. 77, 254-274. https://doi.org/10.1177/0020852311399230 
45. Peerzada, K., 2019. Impact analysis of microfinance intervention on socio-economic welfare of households in dang district gujarat $(\mathrm{PhD}$ Thesis). The Maharaja Sayajirao University of Baroda.

46. Reed, L., Maes, J., 2013. Microcredit Summit Campaign Report, 2011.

47. Sainath, P., 2010. 17,368 farm suicides in 2009. The Hindu 27.

48. Sarstedt, M., Ringle, C.M., Smith, D., Reams, R., Hair Jr, J.F., 2014. Partial least squares structural equation modeling(PLS-SEM): A useful tool for family business researchers. J. Fam. Bu s. Strategy 5, 105-115.

49. Serrano-Cinca, C., Gutiérrez-Nieto, B., Molinero, C.M., 2011. Social and financial efficiency of microfinance institutions, in: The Handbook of Microfinance. World Scientific, pp. 397-418.

50. Shetty, A.J.K., Vasanthi, M., 2019. Micro Finance: An Emerging Horizon of Inclusive Growth. Soc. Sci. Humanit. J. 801-808.

51. Simonsen, M.S., 2016. Effect of Ownership Types on the Social Performance in Microfinance Institutions.

52. Singh, D., Pattnaik, C., Gaur, A.S., Ketencioglu, E., 2018. Corporate expansion during pro-market reforms in emerging markets: The contingent value of group a ffilia tion and diversification. J. Bus. Res. 82, 220-229.

53. Siwale, J., 2013. The work experiences of loan officers in Microfinance: Is it differentforwomen loan officers? Evidence from Zambia.

54. Ta dele, H., Roberts, H., Whiting, R.H., 2018. Microfinance institutions' transparency in sub-saharan Africa. Appl. Econ. 50, 1601-1616.

55. Taylor, M., 2012. The Antinomies of 'Financial Inclusion': Debt, Distress and the Workings of I ndian Microfinance. J. Agrar. Change 12, 601-610.

56. Thomas, J.R., Kumar, J., 2016. Social performance and sustainability of indian microfinance institutions: An interrogation. J. Susta in. Finance Invest. 6, 38-50.

57. Wong, K.K.-K., 2013. Partial least squares structural equation modeling (PLS-SEM) techniques using SmartPLS. Mark. Bull. 24, 1-32. 